\title{
South Africa: Coping with Structural Changes
}

Frikkie Liebenberg and Johann Kirsten

\section{Introduction}

Analyzing the evolution of agricultural research and development policy in South Africa is a fascinating but difficult task, primarily because of the large number of structural, institutional, and political changes that took place during the 20th century. This chapter tracks the history of South Africa's agricultural research and development system against this background, highlighting changes over the past 20 years. Such changes have enabled better documentation of public spending on $R \& D$ and assessments of changes in the methods by which those funds are disbursed.

Public-sector financing remains the dominant source of funding, but, as in so many countries, public funding has come under severe pressure in recent years. In recent years, contributions by producer organizations and international donors to the funding of agricultural research have increased, and universities play a much greater role as research providers. Declining core government funding and changes in leadership and management styles have driven large numbers of the most highly qualified researchers out of South Africa's primary research provider-the Agricultural Research Council (ARC). The prospect of the demise of the agricultural research system led to an initiative to coordinate the funding and provision of agricultural research in South Africa through a National Agricultural Research Forum (NARF). ${ }^{1}$

This chapter presents South Africa's agricultural research and development policy within this historical framework. In the next section we provide a brief overview of the agricultural sector and a review of policy changes with a view to highlighting 
the increased flexibility in input substitution, to which the research system has likely contributed. Thereafter we provide an overview of the overall science and technology policy and a detailed account of agricultural R\&D policy focusing on the institutional structure, priority setting, sources of support, and agricultural R\&D providers. We conclude by discussing major lessons learned and summarizing the debate on a more sustainable national agricultural research system for the future.

\section{Overview of South African Agriculture}

\section{Macroeconomic Environment}

South Africa is a lower-middle-income country where approximately half the population lives in poverty. ${ }^{2}$ According to the results of the 1996 census, the South African population is estimated at 40.584 million, with population growth of about 2 percent per annum-down from 2.5 percent per annum during the 1980s. The census results indicate that total employment in the economy is 9.1 million, of which about 1.8 million are informal job opportunities. ${ }^{3}$ About 34 percent of the economically active population of 27.8 million people are unemployed and seeking work. ${ }^{4}$ The rural unemployment rate for South Africa is 44.2 percent (the urban unemployment rate is 28.7 percent). The Development Bank of Southern Africa (DBSA 2000) estimates that 57 percent of the South African population live in poverty; May (2000) estimates that 30 percent of the urban population are poor, but poverty rates are highest, at about 70 percent, outside urban areas. Many rural people in South Africa live under conditions of deprivation as harsh as those in poorer African countries.

With the fall of the apartheid regime, the government undertook a commitment to reduce rural poverty and adopted programs of land reform and improved service delivery in rural areas. Program results, although commendable in some respects, have been insufficient, slow, and costly relative to expectations and the scale of the task. In the meantime, rural areas face new challenges as the crisis of HIV/AIDS reduces resources flowing to households and severely increases the pressures on families and communities.

\section{Overview of the Agricultural Sector and Changing Productivity}

Primary agriculture, which consists of farm-based production, accounted for 3.4 percent of the GDP of South Africa in 2004 (Table 8.1). Gross value of agricultural production is estimated at 66 billion rand ${ }^{5}$ in 2001-02-an increase of 30.9 percent over 2000-01. Animal products made up 35.3 percent of this figure, field crops 41.0 percent, and horticulture 23.7 percent (Table 8.2). The most important 


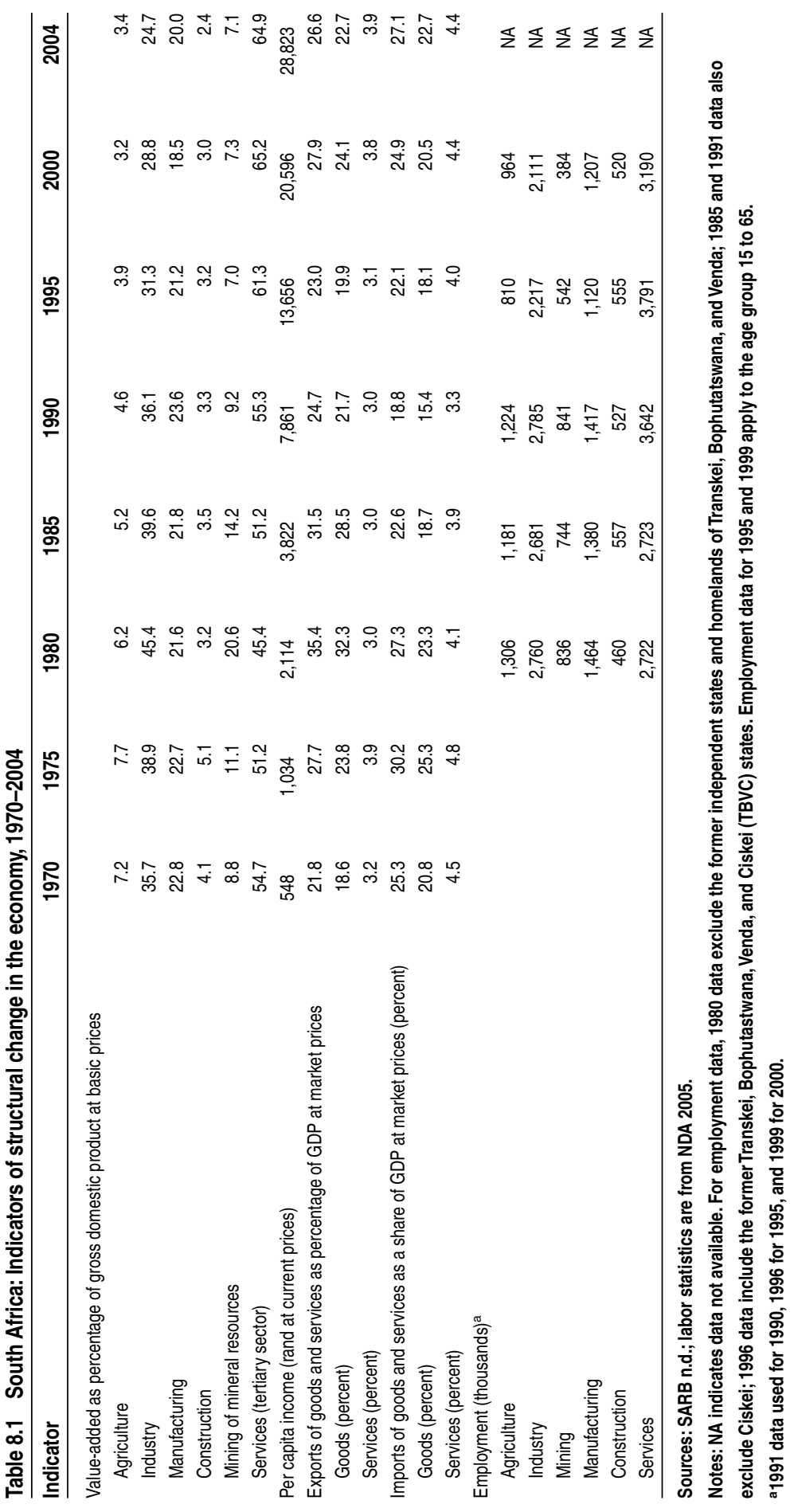




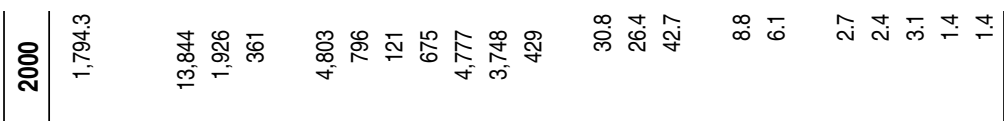

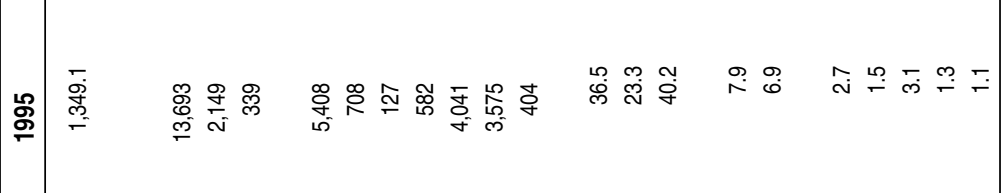

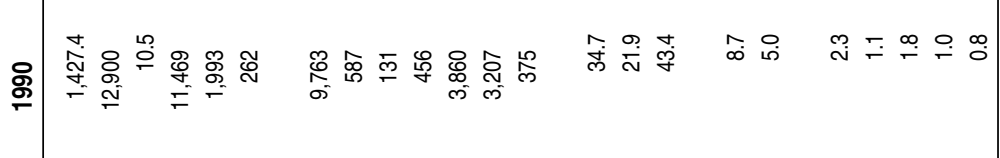

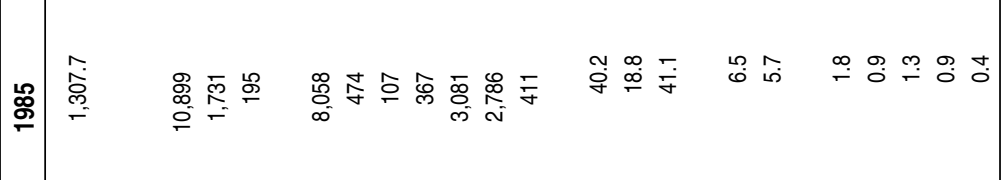

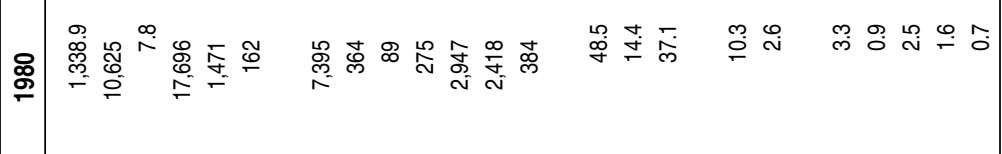

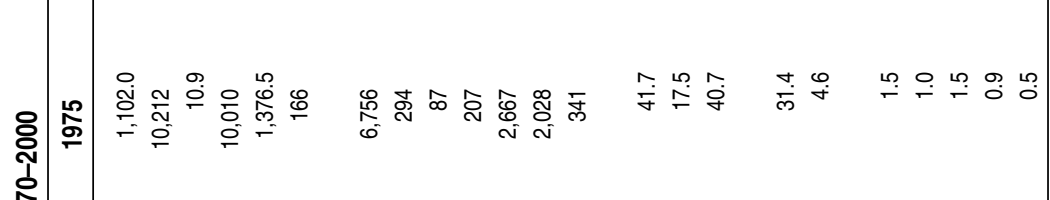

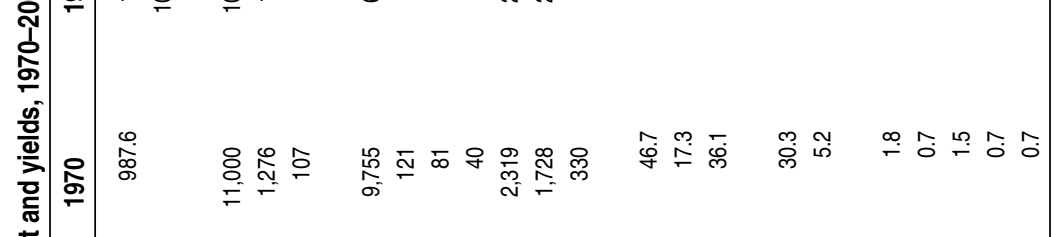

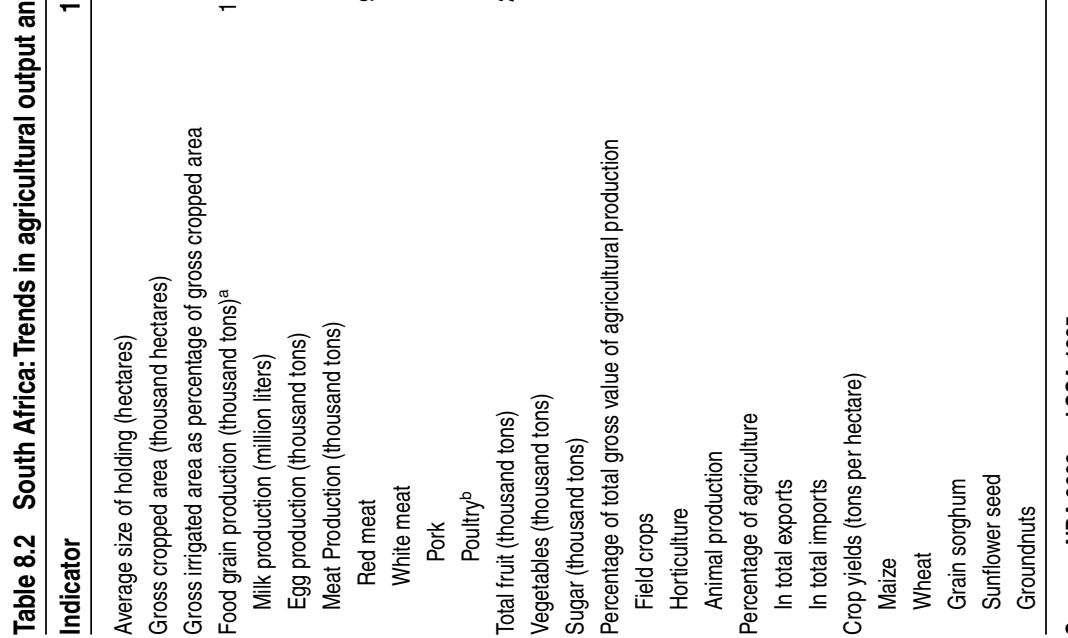

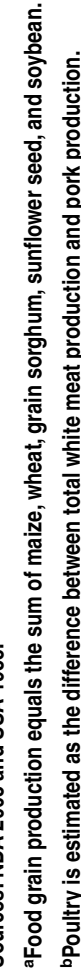


earners of foreign exchange in the agricultural sector are sugar, wine, citrus, and deciduous and subtropical fruits. The agrofood complex, which consists of primary production plus the input and agroprocessing sectors, accounts for around 14 percent of GDP. In 2000 the agrofood complex exported about R16 billion worth of primary and processed food products, nearly 9 percent of South Africa's total exports (Table 8.2).

There are about 60,938 large commercial farmers, who are predominantly but not exclusively white. Commercial farms employed about 1 million workers in 1999, which is 8.1 percent of total formal-sector employment (NDA 2003). Many of these workers live on commercial farms, and their children are educated in farm schools. Thus commercial farms provide livelihoods, housing, and education for the nearly 6 million family members of these 1 million employees.

Furthermore, an estimated 1.3 million households, primarily located in the communal areas of the former homelands, largely produce to meet part of their family's overall needs. Finally, almost all the productive and social activities of rural towns and service centers are dependent on primary agriculture and related activities, which include the increasingly popular and economically significant agrotourism and game farming. Taking all of these activities into account, more than half the provinces, and about 40 percent of the country's total population, are primarily dependent on agriculture and its related industries.

\section{A Review of Policy Changes in South African Agriculture}

Deregulation and liberalization were distinctive features of the agricultural sector of South Africa during the 1980s. ${ }^{6}$ The deregulation process was characterized by changes within the existing institutional structure, through a process of scaling back state intervention. Despite these changes, the main actors in the sector remained the same. This situation changed with the election of the Government of National Unity in 1994, although in agriculture, at least, some direct policy changes were stalled until 1996 (until after the withdrawal of the National Party from the Government of National Unity). The most important policy initiatives taken subsequently included land reform, institutional restructuring in the public sector, the promulgation of new legislation (including the Marketing of Agricultural Products Act and the Water Act), and trade and labor market policy reform. These reforms were intended to correct the injustices of past policy (principally through land reform), to direct the agricultural sector toward a less capital-intensive growth path, and to enhance the sector's international competitiveness.

One of the main features of South African agricultural policy in the 1990s was institutional restructuring. The public-sector agencies supporting the agricultural sector were subjected to the same processes of "provincialization" that came about 
with the adoption of the Interim Constitution. In the case of agriculture, the former "own affairs" (whites-only) and "general affairs" departments were amalgamated to form the core of the new National Department of Agriculture. Functions and staff were redeployed from the former homeland departments of agriculture to new national and provincial departments, and the relationship between the national and provincial departments of agriculture and farmer lobby groups was modified. ${ }^{7}$

Agricultural institutions in the public sector were also reoriented in line with new policy directions. The most radical of these changes occurred in agricultural marketing policy. The promulgation of the Marketing of Agricultural Products Act, No. 47 of 1996, represented a radical departure from the marketing regime to which farmers had been accustomed since the 1930s (Groenewald 2000). Though far-reaching, the deregulation of the 1980s and early 1990s was piecemeal and uncoordinated, and was accomplished within the framework of the old Marketing Act so that policy changes could be reversed easily. The new act changed the way agricultural marketing policy would be managed.

The new South African government also embarked on a process of trade policy reform to reverse decades of "inward industrialization" strategies. The distinguishing characteristic of these reforms was a willingness to expose national businesses to tariffs that were often below the lower bounds negotiated in the Uruguay Round of the General Agreement on Tariffs and Trade (GATT). Whereas agricultural trade had been managed through quantitative controls, the Marrakech Agreement called for the tariffication of all agricultural goods and a phased reduction in the tariffs. South Africa also participated in the renegotiation of the Southern African Customs Union treaty, agreed to the new Southern African Development Community (SADC) trade protocol, and negotiated a free trade agreement with the European Union. In all these cases, the country agreed, in principle, to liberalize agricultural trade further. Finally, the country gained membership in the Cairns Group, ${ }^{8}$ thus signaling its intention to unilaterally liberalize its trade regardless of progress made by developed countries in withdrawing farm support programs.

Effects of policy changes. These policy changes created a number of pressures on farm profits. The analysis of total factor productivity (TFP) in South African agriculture presented below clearly shows that farmers adapted to these changes by decreasing their level of input use, by increasing output from a constant level of input use, or by a combination of these approaches. Whatever the case, productivity has increased. In South Africa, real gross annual capital formation-which was fairly stagnant in the 1980s-has increased at a higher rate since 1990 (Table 8.3). Thus, since the beginning of the 1990 s, farmers have reacted positively to political changes, 
Table 8.3 South Africa: Growth in employment and capital formation, 1947-96

\begin{tabular}{lcc}
\hline Period & $\begin{array}{c}\text { Change in number of farm } \\
\text { employees (percent per year) }\end{array}$ & $\begin{array}{c}\text { Real gross capital formation } \\
\text { (percent per year) }\end{array}$ \\
\hline $1947-96$ & 0.16 & 2.01 \\
$1947-80$ & 1.16 & 2.65 \\
$1980-96$ & -1.86 & 0.68 \\
$1990-96$ & -4.22 & 7.79 \\
\hline
\end{tabular}

Source: Thirtle and van Zyl 1994.

greater access to international markets, and positive real interest rates. The TFP ratio provides a more comprehensive measure of productivity growth in agriculture. The TFP for commercial agriculture in South Africa to 2000 is shown in Figure 8.1, from which it is evident that input use increased slightly faster than the growth in agricultural output from the late 1940s to late 1960s, and so TFP declined. Thereafter, the pace at which aggregate output grew exceeded the growth in aggregate input use (which actually began to decline around 1986-87) and so

Figure 8.1 South Africa: Total factor productivity growth for commercial agriculture, 1947-2000

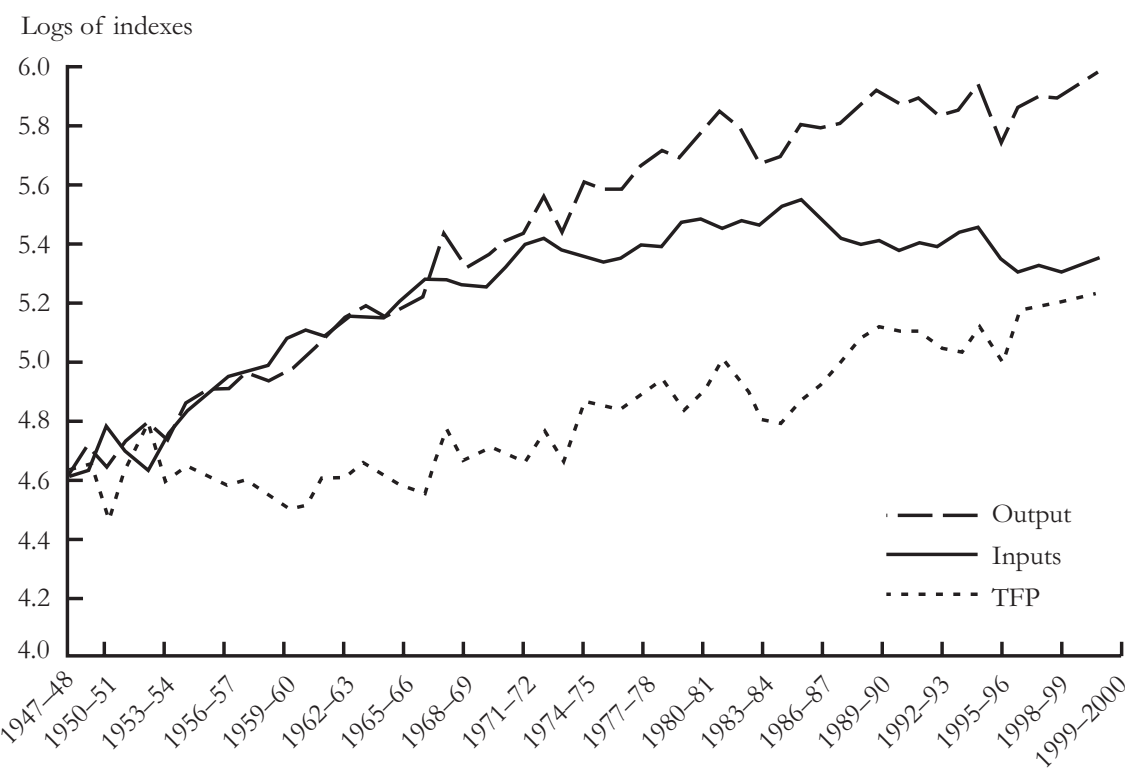

Source: Thirtle 2001. 
TFP rose. Thirtle (2001) described these trends and some ancillary developments in more detail:

- The domestic terms of trade for intermediate and capital goods for commercial farmers were negative throughout the period 1960-96, and hence the input prices they paid rose faster than the output prices they received throughout that period.

- The rate at which the domestic terms of trade turned against commercial farmers worsened during the first phase of deregulation (from roughly 1984); they improved subsequently but were still far higher than between 1960 and 1980 .

- The terms of trade measure the rate of change in the prices of intermediate and capital goods relative to the rate of change in output prices only. TFP measures the relative rate of growth in the value of inputs (including land and labor) and outputs. The data show that TFP growth slowed during the first phase of deregulation, between 1985 and 1994, and increased again thereafter.

- From 1980 through 1990, when inflation rates in South Africa peaked and TFP growth was weakest, net farm income growth was negative (that is, commercial farmers' profit margins grew thinner every year). However, by 1990 TFP growth had recovered sufficiently to cause a positive annual growth in net farm income through 1996.

These TFP results reflect the extent to which farmers have reacted to the costprice squeeze, and it is clear that one of the principal solutions was to change not only the volume of inputs used but also the input mix. Thus farmers' ability to adopt new modes of production depends critically on their ability to substitute inputs in reaction to relative price changes. Some years ago, research showed that farmers' ability to substitute inputs was severely constrained by state intervention in the sector but that this situation had improved as a result of the first stages of deregulation during the 1980s (van Zyl and Groenewald 1988; Sartorius von Bach and van Zyl 1991). Overall, there is some evidence of improved flexibility in input substitution in South African agriculture.

\section{Overall R\&D Policy and Funding Trends}

Like the rest of its economy, the South African science and technology institutions (SETIs) have experienced momentous policy changes since the early 1990s. Prior 
to 1994, SETIs were funded under a policy of "framework autonomy," introduced in 1988. Reduced to its essentials, framework autonomy entailed the following elements:

- The determination of so-called maximum average expenditure per full-time equivalent (fte) staff member (divided into three categories), which was monitored by the Science Council

- The provision of baseline funding, that is, "costs of ... basic infrastructure (expertise and other capacity) necessary for the realization of the aims of the institution" (DNE 1988, p. 43) based on expenditure for those essential activities in 1986-87, annually adjusted in line with appropriate inflation indexes and the available money

- The provision of discretionary financing of, for instance, the agency function, meaning funding of research in the higher-education sector, the operation of national facilities, and so on

In summary, the system of framework autonomy was designed to restrict government control to the overall framework within which the science councils operated, while restricting parliamentary funding to supporting the essential research infrastructure. Within this framework, science councils were given the management flexibility to generate additional income from contracts, and, thus, within limits, to shape their own research agendas.

Each SETI received its budget from its overseeing department (the National Department of Agriculture, for ARC) according to the baseline funding formula. Based on its own internal processes and priorities, the management of SETI allocated its own resources. Science policy was drafted by the Chief Directorate of Science Planning under the Department of National Education (DNE), after which comments from major stakeholders were invited, processed, and submitted to the Science Advisory Council (SAC) for amendment and approval.

Although subject to ARC guidance, the different research institutes were left with significant freedom in setting their own research agendas, in collaboration with industry and peer-review committees. By 1994 these processes still reflected those in existence under the former Department of Agriculture.

In 1994, the Department of Arts, Culture, Science, and Technology (DACST) was established from the relevant elements of the DNE. The creation of DACST introduced a period of rapid changes in science and technology policy in South Africa. Two prominent initiatives taken by DACST since its inception were the 
Table 8.4 South Africa: Allocation of the science budget, 1996-97 and 1999-2000

\begin{tabular}{lccc}
\hline Science Council & $\begin{array}{c}\text { 1996-97 } \\
\text { (million rand) }\end{array}$ & $\begin{array}{c}\text { 1999-2000 } \\
\text { (million rand) }\end{array}$ & $\begin{array}{c}\text { Nominal change } \\
\text { (percentage) }\end{array}$ \\
\hline Agricultural Research Council (ARC) & 319.10 & 279.24 & -12 \\
Human Sciences Research Council (HSRC) & 87.63 & 64.42 & -26 \\
National Research Foundation (NRF) & 138.12 & 162.00 & 17 \\
Medical Research Council (MRC) & 57.91 & 79.57 & 37 \\
Council for Mineral Technology & 82.77 & 81.77 & -1 \\
Council for Geosciences & 63.56 & 63.79 & 0 \\
Council of Scientific and Industrial Research (CSIR) & 274.36 & 310.65 & 13 \\
South African Bureau of Standards (SABS) & 45.93 & 73.72 & 61 \\
Total & $1,069.37$ & $1,115.16$ & 4 \\
\hline
\end{tabular}

Source: DACST 2001.

formulation of a white paper on science and technology (completed in 1996) and the establishment for the National Advisory Council on Innovation (NACI) (legislation approved in 1997). The new policy places a strong emphasis on innovation, and hence on the direction of research resource allocation.

The science and technology branch of DACST took over the administration of an annual budget allocated under the "science vote" of approximately R1.4 billion. ${ }^{9}$ Following the white paper, the principle of baseline funding according to a base formula was replaced, and SETIs now receive their core funding through a parliamentary grant allocated on a competitive basis.

Other sources of funding available to SETIs are the innovation fund and the National Research Foundation (NRF), established in 1998 from the former Foundation for Research and Development. The purpose of the innovation fund is to encourage and enable long-term extensive innovation projects in the higher-education sector, SETIs, civil society, and the private sector. The NRF is mandated to ensure the support of research and the building of research capacity within the highereducation sector and other research institutions. For both undertakings, funds are allocated on a competitive basis. It is envisioned that the innovation fund will grow to about 20 percent of the annual budget, forming a strong mechanism to reallocate resources within the national system of innovation (NSI).

Table 8.4 provides an indication of the government funds earmarked for the different science councils for 1996-97 and 1999-2000. It shows a shift away from agricultural and human sciences toward the Medical Research Council (MRC) and the Council for Scientific and Industrial Research (CSIR).

In 1999-2000 the science budget also included R78.3 million for national facilities, such as the National Laser Centre, and a further R146 million for other programs, such as the innovation fund (R75 million) and special investigations 
(R33 million). The growth in the innovation fund was paid for from the institutional funding of the science councils, with dire consequences for its sustained capacity development. The priority-setting criteria are not favorable to primary agricultural research: they focus, for example, on third-generation biotechnology.

\section{Financing and Provision of Agricultural R\&D}

We provide a brief history of the agricultural research system in South Africa to put the system's current policy and structural changes in perspective.

\section{Institutional Structure}

Prior to $1990 .{ }^{10}$ Following the establishment of the Union of South Africa in 1910, public interventions in agriculture were the responsibility of a central Department of Agriculture. The department also held responsibility for education and training in agriculture. In 1958, the Department of Agriculture was split into two to form the Department of Agricultural Economics and Marketing and the Department of Agricultural Technical Services. The latter focused on production issues and provided services such as agricultural research, education, extension, and regulatory services. In 1962, the Department of Agricultural Technical Services was reorganized as two directorates: the Directorate of Agricultural Research and the Directorate of Agricultural Field Services. The Directorate of Agricultural Research was given responsibility for 10 research centers and directorates that later became institutes. There were also 7 regionally based adaptive research and extension institutes, called agricultural development institutes (ADIs), each with centers for delivering extension services.

Further institutional changes took place in 1970, the most significant of which was the transfer of administrative responsibilities for the faculties of agriculture and veterinary sciences to the Ministry of Education. The Department of Agricultural Technical Services continued to finance research at the universities and supported a substantial, though declining, number of research positions at the various faculties of agriculture.

In rationalizing the public service, the two departments of agriculture were amalgamated in 1980 to form the Department of Agriculture and Fisheries, which was renamed the Department of Agriculture and Water Supply in 1982. Following the establishment of the tricameral legislature, ${ }^{11}$ the department was again divided in 1984 to form the Department for Agricultural Development, largely incorporating the branches of the old Department of Agricultural Technical Services, dealing with "own affairs," and the Department of Agriculture, for "general affairs." 
All funding for research came through the Department of Agricultural Development, which was initially responsible for 11 research institutes, and later 12 . The overall direction of research was mostly determined centrally but was guided by regional development plans. This approach resulted in problems with administration and overall coordination. Links with nationally based institutes, focused on strategic or basic research, and the ADIs also became problematic. The agricultural research system of South Africa at this stage followed a mostly bureaucratic and top-down approach to technology development and transfer.

In a 1984 report by the Committee of Inquiry into Agricultural Service Provision, eight alternative models for the delivery of agricultural research were proposed. The preferred option was the creation of a national agricultural development council. The apartheid dispensation and the various independent homeland governments created problems for its full implementation. ARC (the Agricultural Research Council) was established as a first step toward such a system.

1990 to 1994 . Most of the agricultural research activities under the Department of Agricultural Development were transferred to ARC beginning in April 1992, following the passing of the Agricultural Research Act of 1990. This process was completed only in 1995 . Thus, by the end of this period, ARC had yet to develop an identity as an organization. The lack of consolidation left ARC incapable of facing the changes in South Africa's constitution and in its own governance structure following the democratic elections of 1994.

More important than the reorganization itself, a business-like management style was introduced into ARC institutes. ARC embarked upon a more aggressive cost-recovery program by introducing a user pays principle. This change introduced a stronger client orientation. Targets were set to rapidly increase external funding, with the goal of recovering 30 percent of total expenditures from the commercial agricultural sector (Roseboom et al. 1995). This shift happened much more rapidly than planned as a result of successive cuts in the parliamentary grant to the ARC.

Following the new constitutional dispensation in 1994, nine provinces were created from the former four, and agriculture became the joint responsibility of the national and provincial governments. The previous agricultural development institutes (ADIs) formed the basis of the nine provincial departments of agriculture (PDAs), although the Grootfontein Agricultural Development Institute became the responsibility of the National Department of Agriculture (NDA), where it still resides, because of issues relating to its location.

Funding of agricultural $R \& D$ now came from two streams: ARC received its funding through the National Department of Agriculture, and the PDAs were allo- 
cated a portion of the former national agricultural budget according to a formula. The provincial legislature was not compelled to honor this formula, however.

The current situation. The present structure of the South African national agricultural research system (NARS) consists of agricultural research institutes operating under the ARC, departmental research entities, faculties of agriculture and veterinary sciences, institutes operating under the Department of Environmental Affairs, the Council of Scientific and Industrial Research (CSIR), and some semipublic research agencies supported by industry (see Appendix Table 8A.1). ARC is the principal national agricultural research entity. It oversees 13 agricultural research institutes with a network of experimental farms and modern equipment throughout the country, and, with the exception of sugarcane, supports all the major agricultural commodities in South Africa.

Two groups were created to coordinate and integrate these efforts: MINMEC, an interministerial committee headed by the national minister of agriculture and comprising the members of the provincial executives of agriculture, and the Interdepartmental Technical Committee on Agriculture (ITCA), comprising department heads. ITCA had several subsidiary technical and advisory committees. Most of these were disbanded for lack of effectiveness, except for those dealing with naturalresource management and veterinary services. In early 2003 the Agricultural Economics Working Group was reintroduced by ITCA.

Funding for the PDAs and, as such, for provincial agricultural research began to deviate from the 1995 formula guidelines. Provincial R\&D capacity dwindled and in some cases ceased. High costs and poor restructuring plans led to the disappearance of agricultural research in some provinces, such as the Eastern Cape. A reasonable degree of research competence exists in only two provinces- the Western Cape (Elsenburg) and Kwazulu-Natal (Cedara)—but these programs remain severely underfunded in some aspects. Most of the provinces had to rely on donor funding and the operations of NGOs and producer or commodity organizations. ARC has provided increasing support to the provinces.

The management of ARC has changed substantially since the new science and technology policy was introduced in 1997. Following various reviews of the agricultural research system and strong criticism of the way ARC was managed, the governance structures were changed, and a number of research institutes were merged. One of the important criticisms was that ARC research dealt mainly with capital-intensive farming operations, thereby benefiting commercial farmers rather than farmers from previously disadvantaged communities. The reviews and recommendations required a shift in research focus and service provision by the ARC while its parliamentary grant dwindled in line with the perceived new direction in 
the science system. Changes in leadership, among other factors, left ARC increasingly isolated and its stakeholders uninformed of the consequences of these changes. It is possible that ARC's council, being relatively inexperienced, did not foresee and clearly communicate the consequences of the changes satisfactorily. To become an active and integrated member of the country's agricultural research system, the $\mathrm{ARC}$ was under pressure to improve its performance and ensure the relevance of its research.

This process involved interactions with a number of stakeholders during 1999. In a series of meetings with PDAs and representative bodies in organized agriculture, stakeholders were asked to critique ARC's performance as an agricultural service provider. Insights gained from this exercise enabled ARC to initiate strategic workshops on its research agenda and on the funding of agricultural research. A system was also introduced whereby research on the problems and needs of resourcepoor farmers was detached from the overall parliamentary grant and managed under a separate program for sustainable rural livelihoods. In addition, commercialization of research outputs was given greater emphasis.

\section{Setting Priorities}

Oversight of the national system of innovation is the responsibility of the National Advisory Council on Innovation (NACI), which was established to advise DACST on the direction of scientific research. This entity, together with the requirements of the new Public Finance and Management Act (PFMA), plays a major role in influencing research priorities. Under this new act, and in line with the existing medium-term expenditure plan, public entities like ARC are expected to submit three-year budget requests directly linked to strategic plans.

Within ARC, the national institutes previously relied primarily on peer reviews and institute-level priority setting under a regime of (mostly) state-funded research, with the relative share of government funding for each institute remaining fairly stable. The change to the national system of innovation, followed by the subsequent cuts in core funding, mandated a change in the relative share of core funding among institutes. The introduction of corporate programs in 1999 was seen as both a means to drive greater integration in research activities between institutes within a systems-research framework, and a framework to introduce interinstitute priority-setting mechanisms. However, the significant differences in the ability of industries and other clients to pay for research and the severity of the cuts in core funding have led to current core funding ratios that reflect the ability to pay rather than any serious national priority considerations.

Research priorities are also determined by DACST's recently completed national research and development strategy. This department has also been split into two 
separate departments, with the Department of Science Technology now being responsible for the science vote (DST 2002). This national strategy identifies research needs in all sectors of the economy, including agriculture and agribusiness. These priorities influence the allocation of the different competitive funds, such as the innovation fund, the Technology and Human Development Research for Industry Program (THRIP), and the funding programs of the National Research Foundation. Most universities doing agricultural research, as well as NGOs, submit applications to these funds.

Previously, funding for agricultural research in the provinces followed the priorities of the provinces' agricultural development programs. The establishment of the provincial departments of agriculture, and the associated restructuring initiatives, has led to a breakdown in this practice. ARC is now assisting provinces to redevelop their research capacity. There is very little coordination among the various players in setting research priorities in agriculture. Universities, ARC, and the PDAs rarely collaborate in research and often compete for research funds. The new NARF (described earlier) may improve this situation, but it has yet to secure funding for its initiatives in this regard (NDA 2001).

\section{Sources of Funding for Agricultural R\&D}

The funds allocated to agricultural research in South Africa come from four sources. At the central-government level, the science budget is allocated by DST and various national government departments. Other national revenue sources include commodity trusts and levies from producer organizations and research funding from private-sector enterprises. ${ }^{12}$ The increasing prominence of these enterprises in terms of research funding and the use of research services distinguishes South Africa's NARS from those of other African countries.

In addition to the structural changes in the agricultural $R \& D$ system, competitive bidding with other science councils for parliamentary grants (PGs) was introduced in 1997-98. Furthermore, it was decided that all external research contracts would be based on full cost recovery. This principle was not readily accepted by the various commodity organizations that fund research. As a compromise, a 50:50 cost-sharing arrangement was negotiated between the relevant institutes and commodity organizations.

Other major funders of agricultural research over the past five years have been various commodity trusts, which were established following market deregulation that involved the abolition of all marketing boards. The assets of these boards were transferred to trusts such as the Maize Trust, the Wool Trust, and the Red Meat Trust, and the returns from these assets are used to fund the activities of producer organizations and to fund agricultural research and the activities of the producer 
Table 8.5 South Africa: Annual contribution by commodity organizations to agricultural research, 1999-2001

\begin{tabular}{lrrr}
\hline & \multicolumn{3}{c}{ Contribution (thousand rand) } \\
\cline { 2 - 4 } Source & \multicolumn{1}{c}{$\mathbf{1 9 9 9}$} & $\mathbf{2 0 0 0}$ & $\mathbf{2 0 0 1}$ \\
\hline Trust contributions & & & \\
$\quad$ Animal & $3,578.09$ & $3,468.82$ & $7,222.26$ \\
Crops & $13,060.67$ & $18,732.63$ & $21,338.85$ \\
$\quad$ Horticulture & $5,280.91$ & $4,200.00$ & $3,684.21$ \\
$\quad$ Subtotal & $21,919.67$ & $26,401.45$ & $32,245.32$ \\
Levy income & & & \\
$\quad$ Crops & $11,194.27$ & $11,491.69$ & $12,337.12$ \\
$\quad$ Horticulture & $19,156.31$ & $25,665.74$ & $27,521.31$ \\
$\quad$ Subtotal & $30,350.58$ & $37,157.43$ & $39,858.43$ \\
Total contributions from commodity organizations & & & \\
$\quad$ Animal & $3,578.09$ & $3,468.82$ & $7,222.26$ \\
$\quad$ Crops & $24,254.95$ & $30,224.32$ & $33,675.97$ \\
$\quad$ Horticulture & $24,437.22$ & $29,865.74$ & $31,205.52$ \\
Total & $52,270.25$ & $63,558.88$ & $72,103.75$ \\
\hline
\end{tabular}

Source: Information provided by various trusts and commodity organizations (personal communications).

organizations. Table 8.5 provides an indication of the extent of research funding provided by commodity trusts and by statutory and voluntary levies managed by certain producer organizations since 1999.

Figure 8.2 shows the flow of funds within the South African NARS for 1999-2000. At the central-government level, the parliamentary grant from the science vote totaled R295.5 million, consisting of R292.9 million allocated to ARC and the balance allocated by the CSIR to its Division of Food, Biological, and Chemical Technologies (DFBCT). The various national departments allocated a further R68.1 million to agricultural research through performance and service contracts and competitive-bidding funds: the latter were mainly allocated through the THRIP programs and the innovation fund administered by the NRF, as well as the lead programs of DACST. An amount of R29.2 million is generated internally by ARC from its own resources.

Other public sources include R4.5 million allocated to agricultural research by the Water Research Commission. This represents 9.1 percent of the total research budget of the Water Research Commission, which receives its funding from a levy paid by all water use authorities. Funding from commodity and producer organizations supports research commissioned by the commodity trusts (R26.4 million) and levy income (R39.2 million for nonsugar commodities, R48.8 million for sugar). Funding from private enterprises comes mainly from input suppliers and 
Figure 8.2 South Africa: Funding channels for agricultural R\&D, 1999-2000

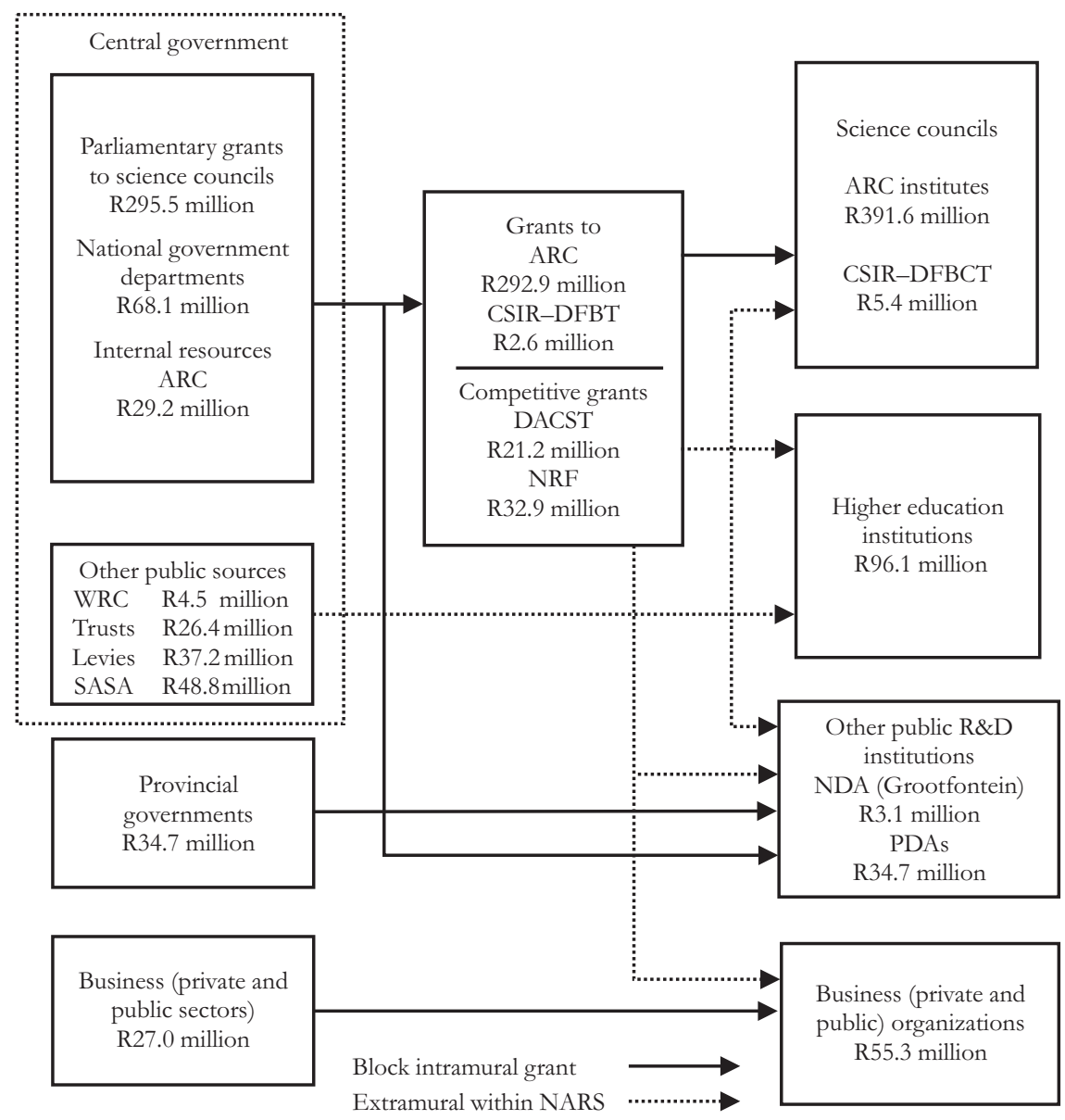

Sources: Compiled by authors from various sources, but mainly from Liebenberg, Beintema, and Kirsten 2004.

Notes: Data are nominal South African rand. Values may not tally exactly with those reported in other tables and figures because estimates of researcher expenditures were used elsewhere, and ARC corporate expenditures are included here.

WRC = Water Research Commission; SASA = South African Sugar Association. 
agroprocessors, who outsource some research on a contract basis but also do inhouse research. Monies allocated from these sources amounted to R27.0 million in 1999-2000.

ARC and the higher-education institutions dominate expenditure by research performers. Total expenditure in 1999-2000 is estimated at R586.2 million, of which R139.4 million came from nongovernment income sources. The total donor contribution to South African research is difficult to estimate but is assumed to be relatively small.

Agricultural research at the different faculties of agriculture is also funded from a range of sources. Commodity organizations and private companies generally support the major and longer-term projects; funds are also supplied to successful bidders under the innovation fund and the NRF. In addition, donor agencies have also recently provided some support for university research and postgraduate teaching initiatives.

\section{Agricultural R\&D Patterns}

ARC is by far the largest provider of agricultural research in South Africa, employing 59.8 percent of the country's agricultural researchers in 1999 and accounting for 57.9 percent of total agricultural research expenditure-slightly more than ARC's 54 percent of total share at the time of its establishment (Roseboom et al. 1995). Universities have also shown strong growth in market share since 1992 (Table 8.6).

The situation appears to have changed significantly since 2000. The number of research staff at ARC dropped from 751 in 1992 to 682 (non-fte) in 2000 and 525 in April 2003. The biggest change in terms of qualifications was among Ph.D.- and M.Sc.-qualified researchers. Ph.D. numbers fell from 206 in 1997 to 179 in 2000. Of greater concern, ARC records at the end of April 2003 reflected only 144 staff with Ph.D.s employed at all the institutes (only 87 of whom were researchers), a decline of 35 . The corresponding decline for research staff holding M.Sc. degrees is 41. By inference, 76 key research staff have left ARC since 2000, adding to the decline of the previous few years. This rapid decline is disturbing and could signal the demise of the agricultural research system in South Africa.

Ratios of support staff to scientists dropped from as high as 10.7:1 in 1992 to 3.9:1 in 2001. The ratio of technicians to researchers in ARC institutes fell from 1.7:1 in 1992 to $0.8: 1$ in 2001, indicating that research support is dwindling and that the remaining researchers and technicians must now spend more of their time on mundane duties. This trend has severe implications for ARC's capacity to maintain performance levels, which in turn will strongly affect the ability of South Africa's agricultural sector to support regional and local rural development initiatives. 


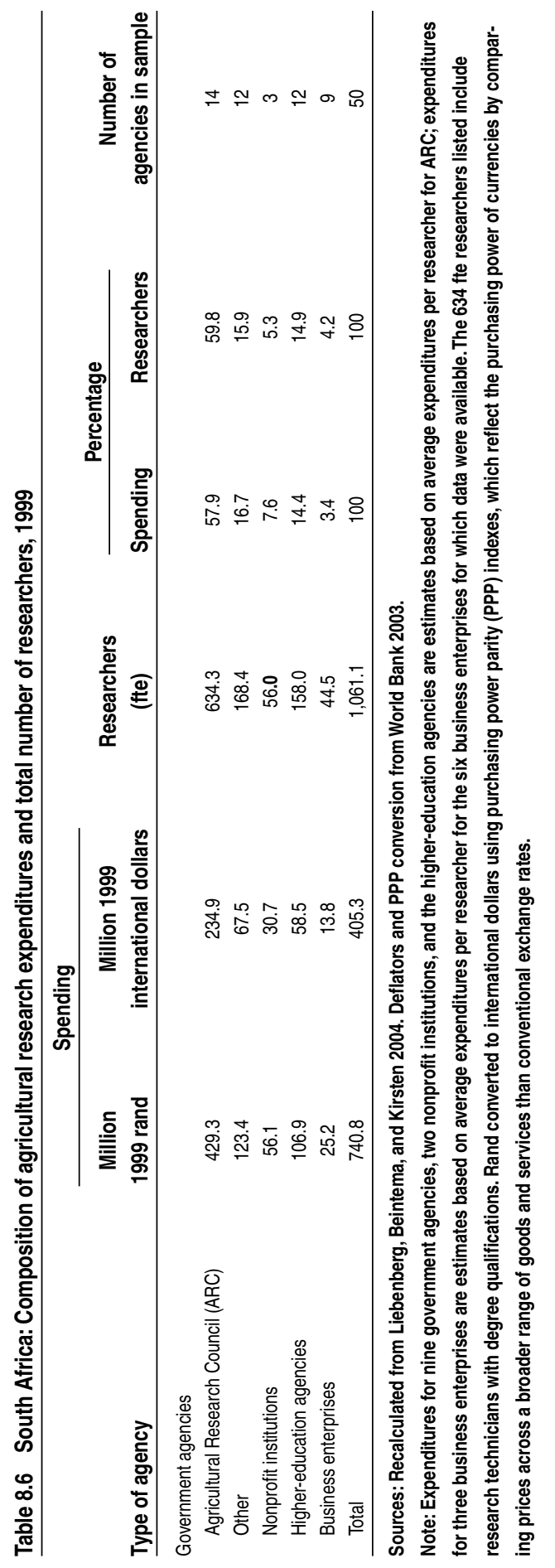




\section{Figure 8.3 South Africa: The history of the parliamentary grant to the Agricul- tural Research Council, 1992-2002}

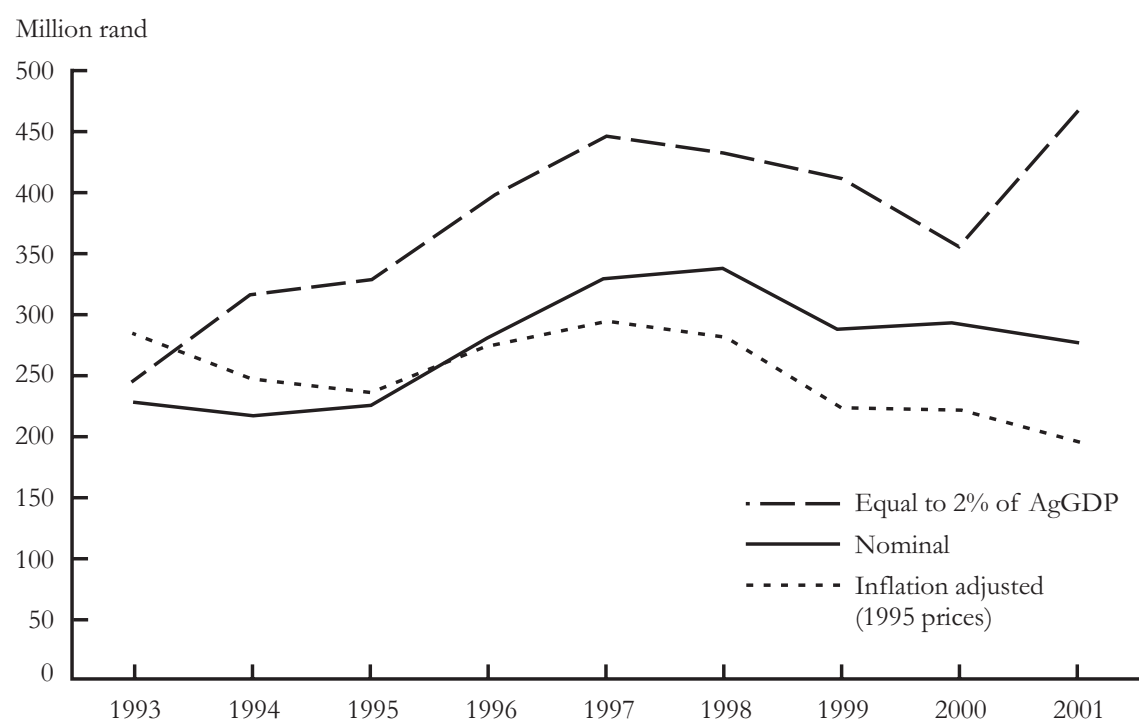

Sources: Compiled by authors from NDA 2003; and ARC Annual report, 1993-2002.

The budgetary pressures resulting from the drop in the parliamentary grant could be the main reason behind the reductions in these ratios.

ARC funding provided by the government through the parliamentary grant system dropped from a peak of R337 million in 1997-98 to R262 million in 2001-02. The history of the parliamentary grant to ARC is well illustrated by the trend in Figure 8.3. The extent of the decline in funding is emphasized by the rapidly declining real value of the grant. By 2001-02, ARC received only 55 percent, in real terms, of the parliamentary grant it received in 1992. As a consequence, external income had to increase significantly to maintain overall spending at an estimated R450 million for 2001-02. Also shown in Figure 8.3 is ARC's level of baseline funding had it been maintained at 2 percent of AgGDP. Under the new Agricultural Sector Strategy (NDA 2001), it is envisioned that this target should be in the range of 3 percent.

Table 8.7 shows sources of ARC funding from 1998 to 2000, and relative shares for each year. External income for ARC came from commodity and producer organizations and donor funding. Income from commodity organizations contributed between 11.1 and 12.9 percent of ARC expenditure in the period 1998-2000. As shown in Figure 8.2, commodity organizations, as a whole, fund a total of 19.7 
Table 8.7 South Africa: Agricultural Research Council funding sources, 1998-2000

\begin{tabular}{|c|c|c|c|c|c|c|c|c|c|}
\hline \multirow[b]{3}{*}{ Source } & \multicolumn{6}{|c|}{ Total funding } & \multirow{2}{*}{\multicolumn{3}{|c|}{ Funding share }} \\
\hline & \multicolumn{3}{|c|}{ Million rand } & \multicolumn{3}{|c|}{$\begin{array}{c}\text { Million } \\
\text { international dollars }\end{array}$} & & & \\
\hline & 1998 & 1999 & 2000 & 1998 & 1999 & 2000 & 1998 & 1999 & 2000 \\
\hline Government & 304.5 & 282.9 & 265.0 & 166.6 & 154.8 & 145.0 & 66.6 & 63.8 & 62.0 \\
\hline Bilateral donors & 0.2 & 2.3 & 3.6 & 0.1 & 1.3 & 2.0 & 0.1 & 0.5 & 0.8 \\
\hline Multilateral donors & 2.5 & 0.9 & 0.8 & 1.3 & 0.5 & 0.4 & 0.5 & 0.2 & 0.2 \\
\hline Producers and marketing boards & 52.9 & 57.4 & 47.4 & 28.9 & 31.4 & 25.9 & 11.6 & 12.9 & 11.1 \\
\hline Public and private enterprises & 50.3 & 62.5 & 60.9 & 27.5 & 34.2 & 33.3 & 11.0 & 14.1 & 14.2 \\
\hline Own income & 32.1 & 29.2 & 44.2 & 17.5 & 16.0 & 24.2 & 7.0 & 6.6 & 10.3 \\
\hline Other & 14.7 & 8.3 & 5.8 & 8.0 & 4.5 & 3.2 & 3.2 & 1.9 & 1.4 \\
\hline Total & 457.2 & 443.5 & 427.7 & 249.9 & 242.7 & 234.0 & 100 & 100 & 100 \\
\hline
\end{tabular}

Sources: Recalculated from Liebenberg, Beintema, and Kirsten 2004. Deflators and currency conversion from World Bank 2003.

Note: See Table 8.6 for details of international dollars.

percent (R112.4 million) of total R\&D expenditure in South African agriculture. A few statutory levies were introduced by producer organizations as a way to raise funding for agricultural research, among other things. Voluntary levies are also used by some commodity groups, but income from these sources is highly unstable. Donor funding to ARC is growing, but access to it is severely limited by policy constraints. However, it seems that more donor funding has been flowing to universities for basic and applied agricultural research. Private funding to ARC is estimated at 14.2 percent of total ARC funding, and intramural research in many agricultural input firms has been growing because of the high returns on intellectual property rights (IPR) and patents in this industry. In addition, many private companies have awarded research contracts to universities. ARC's "own income" from royalties and IPR increased over the three years shown, from almost 7 percent to 10.3 percent.

Despite the growth in external funding, the government (through the parliamentary grant and a range of contracts) remains the largest single source of funding (around 62 percent) for ARC. However, the dual accountability of ARC institute directors to public and private funders is becoming a serious issue in resource-allocation decisions.

\section{Institutional Accountability Mechanisms}

Science Councils report both to the line ministry and to the Minister of Arts, Culture, Science, and Technology on their annual performance. For PDAs, the line of reporting is under the various provincial legislatures, with coordination through 
ITCA. Universities report to DNE, coordinated by a committee of the heads of the agriculture faculties. Given the strong degree of autonomy of the various research service providers, no single authority has control over the activities of all the country's research providers. This situation reinforced the need for establishing the NARF, which was recommended as early as 1996 but only eventuated in 2002. Although recognized and funded by the NDA, the NARF is still battling to become fully operational.

The promulgation of the Public Finance and Management Act in 1999 (Act 1 of 1999) has led to a legal requirement on public entities (parastatals) to report to Parliament on their service delivery according to a set of formal, predetermined objectives and performance indicators. DACST has taken the lead in harmonizing the diverse basis of reporting from the various science councils to authorities such as NACI and Parliament.

Using a "balanced scorecard" technique, a set of 25 indicator areas has been identified in the areas of finance, stakeholder satisfaction, internal business organization, and internal learning and growth. To include the performance of delivery on equity legislation, a fifth reporting category was identified and included: human resources and transformation. Each science council developed its own set of indicators for measuring and reporting on performance under each of these categories (where applicable). Steps are being implemented to develop greater uniformity in the measures used by the various science councils to facilitate intercouncil comparisons and reduce the administrative burden of reporting.

In 1995, ARC established a small impact-assessment unit, the Group for Development Impact Analysis, to introduce social sciences research into ARC's activities. Being small, the unit was located centrally and provides services to institutes throughout the country. One of the unit's first initiatives was to contract a series of aggregate rate-of-return studies (Table 8.8). Results show that on average, the social rate of return on the investment in agricultural research has been positive and fairly high. A number of cost-benefit impact-assessment case studies have also been done.

Further, the unit actively participated in project feasibility studies and the training of researchers and research managers in project-level monitoring and evaluation techniques. A further area of activity since 1998 involved support to corporate management in policy advice and planning. Although, to date, formal mechanisms for priority setting have been restricted to the institute level, there is a growing need to expand them to the corporate level within ARC. Stakeholders requested this change in March 2001. In the seven years since its establishment, the demand for the unit's services and appreciation of the importance of the information it generates have grown exponentially, although trends in public funding to ARC have 


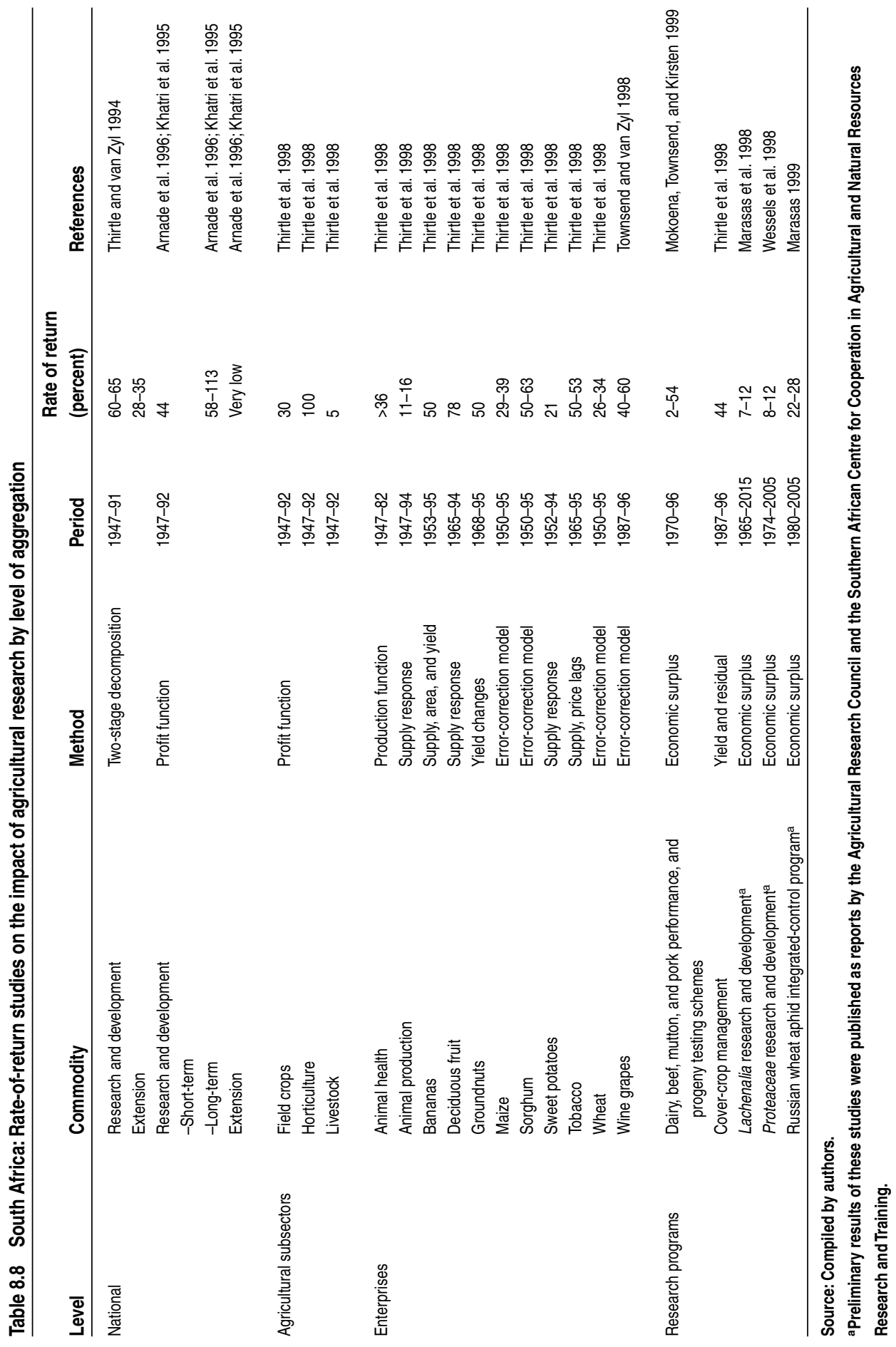


stymied efforts to expand the unit by placing personnel in the institutes. Unit-facilitated policy workshops disseminating the information developed have succeeded in building understanding among key NARS stakeholders regarding the future direction of agricultural research. In line with the exodus of researchers from the ARC, the staffing of the unit has fallen from 11 in 2000 to 2 in April 2003.

\section{The Provision of Agricultural R\&D Services}

The dominance of ARC in South African agricultural research is evident through an overview of its various research providers (Table 8.9).

Government and local agencies. The national government has introduced a number of programs to direct resources toward priority initiatives, responding to pressure to fulfill its growth and development strategy and to deal with the difficulties experienced by provincial research agencies in adapting to their new mandate. These changes have directly affected ARC's priorities and activities. ARC was continuously urged to adjust its operations in line with the seven presidential imperative programs (PIPs), one of which focuses on rural development. Government departments were clustered around these PIPs according to their potential ability to deliver on the initiatives from their existing budgets. Meetings between the minister of agriculture and the provincial ministers (MINMEC) have also identified five-year priorities for agriculture that closely relate to the PIPs. Since November 2001, the new sector strategy for agriculture has formed the basis for policy and service-provision alignment (NDA 2001). Producer and commodity organizations often enter partnerships with public-sector R\&D service providers such as ARC. The greatest successes have come when ARC has taken the lead in project management, and the universities, provincial departments, producer organizations, and farmers have each contributed financially or in kind.

Universities. Faculties of agriculture at the larger universities are in a much better position to maintain capacity under the current circumstances. Core funding for universities is provided by the National Department of Education (NDE) and primarily underwrites salaries and overhead. Direct research costs are usually funded through research contracts with producer organizations, private companies, and some international donors. In addition, researchers at universities compete for research funds such as the innovation fund and annual grant funding for researchers from the NRF. The large variety of funding sources makes it difficult to develop a clear picture of spending on agricultural $R \& D$ by universities. There is growing concern that universities are venturing into applied research, thereby usurping potential 
Table 8.9 South Africa: Agricultural research expenditure by institutional category, 1992-2000

\begin{tabular}{|c|c|c|c|c|c|c|c|c|c|}
\hline Institution & 1992 & 1993 & 1994 & 1995 & 1996 & 1997 & 1998 & 1999 & 2000 \\
\hline \multicolumn{10}{|l|}{ Million 1999 rand } \\
\hline \multicolumn{10}{|l|}{ Government agencies } \\
\hline Agricultural Research Council (ARC) & 422.9 & 414.2 & 404.4 & 480.3 & 494.1 & 483.4 & 519.5 & 452.9 & 429.3 \\
\hline Other & 126.9 & 135.0 & 126.5 & 138.3 & 133.5 & 129.5 & 130.2 & 116.3 & 123.4 \\
\hline Subtotal & 549.8 & 549.1 & 530.9 & 618.6 & 627.6 & 612.9 & 649.7 & 569.3 & 552.6 \\
\hline Nonprofit institutions & 60.6 & 55.0 & 49.3 & 51.6 & 53.1 & 50.9 & 54.2 & 56.7 & 56.1 \\
\hline Higher-education agencies & 72.8 & 78.9 & 77.0 & 85.8 & 82.8 & 80.2 & 101.4 & 101.7 & 106.9 \\
\hline Business enterprises & 27.2 & 27.1 & 27.6 & 28.7 & 27.7 & 26.0 & 26.6 & 21.3 & 25.2 \\
\hline Public total & 683.2 & 683.1 & 657.2 & 755.9 & 763.5 & 744.0 & 805.3 & 727.7 & 715.6 \\
\hline Total & 710.4 & 710.1 & 684.8 & 784.6 & 791.2 & 770.0 & 831.9 & 749.0 & 740.8 \\
\hline \multicolumn{10}{|l|}{ Million 1999 international dollars } \\
\hline \multicolumn{10}{|l|}{ Government agencies } \\
\hline Agricultural Research Council (ARC) & 231.4 & 226.6 & 221.2 & 262.8 & 270.3 & 264.5 & 284.2 & 247.8 & 234.9 \\
\hline Other & 69.4 & 73.8 & 69.2 & 75.7 & 73.0 & 70.8 & 71.3 & 63.7 & 67.5 \\
\hline Subtotal & 300.8 & 300.4 & 290.5 & 338.5 & 343.4 & 335.3 & 355.5 & 311.5 & 302.3 \\
\hline Nonprofit institutions & 33.2 & 30.1 & 27.0 & 28.2 & 29.1 & 27.9 & 29.7 & 31.0 & 30.7 \\
\hline Higher-education agencies & 39.9 & 43.2 & 42.1 & 46.9 & 45.3 & 43.9 & 55.5 & 55.6 & 58.5 \\
\hline Business enterprises & 14.9 & 14.8 & 15.1 & 15.7 & 15.1 & 14.2 & 14.6 & 11.6 & 13.8 \\
\hline Public total & 373.8 & 373.7 & 359.5 & 413.6 & 417.7 & 407.0 & 440.6 & 398.1 & 391.5 \\
\hline Total & 388.7 & 388.5 & 374.6 & 429.3 & 432.9 & 421.3 & 455.2 & 409.8 & 405.3 \\
\hline
\end{tabular}

Sources: Recalculated from Liebenberg, Beintema, and Kirsten 2004. Deflators and currency conversion from World Bank 2003. Notes: Expenditures for nine government agencies, two nonprofit institutions, and the higher-education institutions are estimates based on average expenditures per researcher for ARC; expenditures for three business enterprises are estimates based on average expenditures per researcher for the six business enterprises for which data were available. The 634 FTE researchers listed include research technicians with degree qualifications. See Table 8.6 for details of international dollars.

projects from ARC. This shift is partly a result of commodity organizations either perceiving that ARC's capacity is declining or being attracted by lower rates charged by universities.

International agencies. The CGIAR system has provided useful support and information since 1994. There has been little direct involvement in South African agricultural research, however, apart from a few donor-driven projects. Involvement is increasing, and the establishment of a regional office for the International Water Management Institute (IWMI) in Pretoria is an example of this growing trend. IWMI works in close collaboration with ARC, the government, 
and universities on issues related to the rehabilitation of irrigation schemes, the development of an irrigation policy, and the development of irrigation scheme management.

Regional R\&D organizations, such as the Southern African Centre for Cooperation in Agricultural and Natural Resources Research and Training (SACCAR), are becoming more important. SACCAR, under the auspices of the SADC, used to allocate certain research initiatives to specific SADC member states. Following the restructuring of SADC, SACCAR now takes greater direct responsibility for research. Member states no longer have the sole responsibility to fund and manage these initiatives, with only the review and consultation of the SACCAR council and its subsidiary technical committees. ARC used to represent South Africa's R\&D interests at SACCAR. Whereas universities still have representation, NDA has now taken over this responsibility, for all foreign representation and liaison of agricultural R\&D.

The World Bank-funded Special Program on African Agricultural Research (SPAAR) has also been changed to a more permanent initiative with the creation of the Forum on Agricultural Research in Africa (FARA) in Addis Ababa in April 2001. The intention is to provide a forum for harmonizing agricultural $R \& D$ in Africa through the initiatives of the three regional agricultural research organizations in Sub-Saharan Africa: SACCAR, the Association for Strengthening Agricultural Research in East and Central Africa (ASARECA), and the Western and Central African Council for Agricultural Research and Development (CORAF). This arrangement allows Africa to take greater ownership of its R\&D. The Mbeki government is also taking the lead in implementing the New Partnership for Africa's Development (NEPAD), which has a strong focus on agricultural development.

\section{Lessons Learned and Future Challenges}

The changes that began in the early 1970s led to an increasingly fragmented agricultural research system, and efforts to integrate the system's components and improve overall efficiency are incomplete. In the process of reforming the national agricultural research system in South Africa, several lessons have been learned.

It is important to maintain continuity in NARS leadership and for those leaders to have direct communication with institutional leaders. Commitment to goals, and the initiatives implemented to achieve them, is imperative, as is the capacity to monitor and adjust to changes. Ad hoc, uncoordinated responses to change within such a complex system as South Africa's NARS is, perhaps, the most important cause of fragmentation and duplication of effort. 
Stakeholders must have access to appropriate information and analyses when making decisions, and their roles and responsibilities must be clearly established and understood. Memoranda of understanding or contracts can be used to communicate and clarify this information. Throughout, the focus should be on the coordination, content, and evaluation of programs.

A crucial factor is the policy environment that supports mobilizing funds, developing and maintaining the human-resource capacities of the system, and facilitating communication. This is one of the most neglected areas from the viewpoint of agricultural R\&D policy in South Africa. These issues are emphasized only periodically; consistent effort by a critical mass of policy researchers is needed, as is an effective, world-class agricultural science fraternity to encourage greater numbers of students to train in the agricultural sciences. A substantial scholarship program for students is urgently needed to redress the substantial loss of qualified scientists from South Africa.

The increased role of private organizations and commodity trusts in funding the ARC illustrates the general experience of public research entities that increasingly rely on nonpublic sources of funding. Commodity trusts have shown a strong willingness and ability to increase their contributions. However, the amount of funding from these sources fluctuates markedly depending on industry market conditions. In South Africa it is also susceptible to the vagaries of sectoral politics and the failure of public entities to allow private funders of public research to secure intellectual property rights on research output. If public-research service providers fail to reach mutually acceptable positions with private funders on intellectual property rights issues (and, relatedly, the allocation of research resources), they may well be unable to ensure a stable flow of adequate funding and retain competent staff.

The establishment of the NARF in 2002 marked the beginning of a new phase in South Africa's agricultural R\&D. The NARF could be critical in securing not only the future of agricultural research in South Africa but also the sustained international competitiveness and prosperity of agriculture in South and southern Africa. Unfortunately, since its establishment, the NARF has failed to become operative as a policy advisory body or to formulate appropriate policy responses to the issues listed here. ARC's experience over the past 10 years could be invaluable in the planning and implementation of a much more effective NARS into the future. 


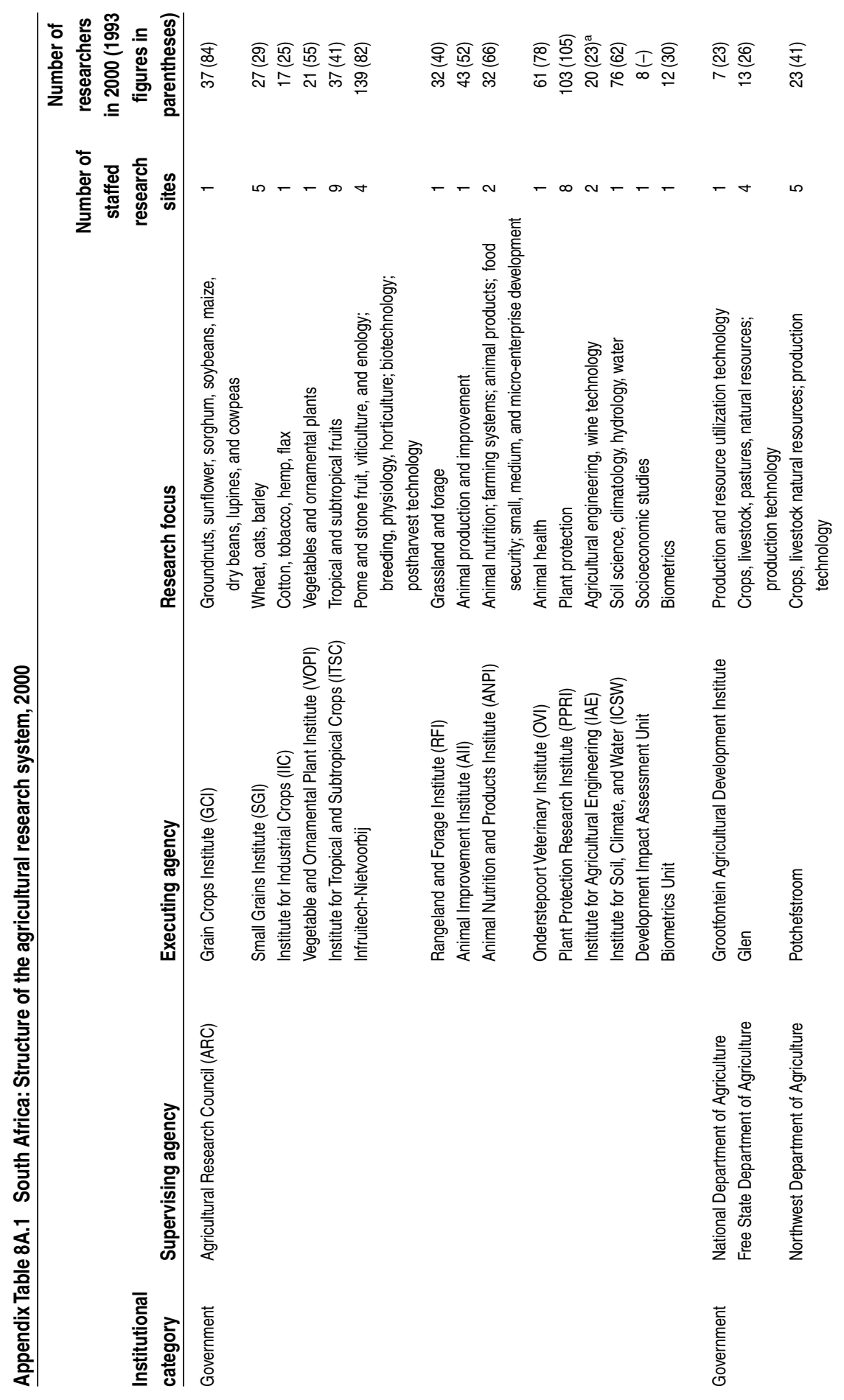




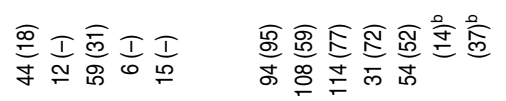

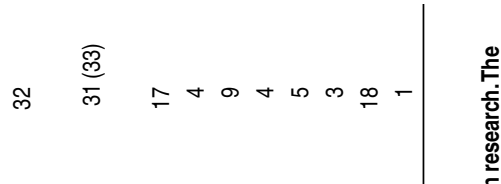

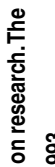

๑ m $\sim \sim$

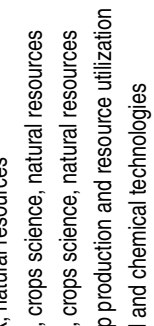

궁 ङ

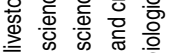

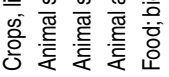
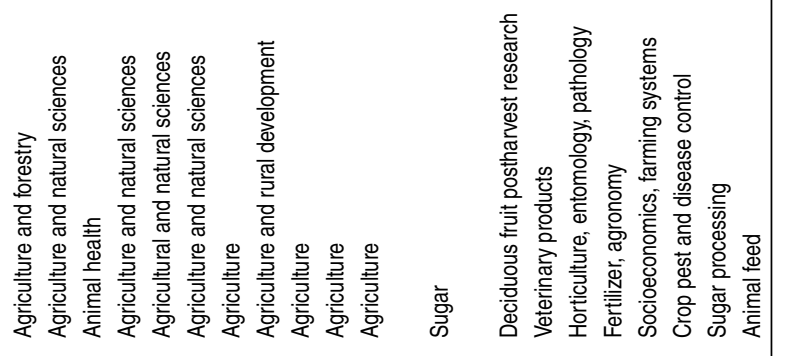

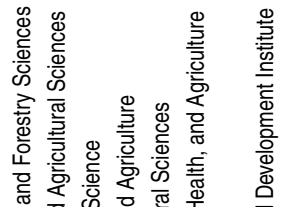

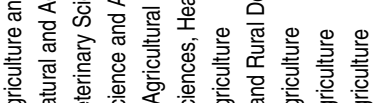

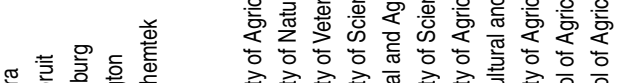

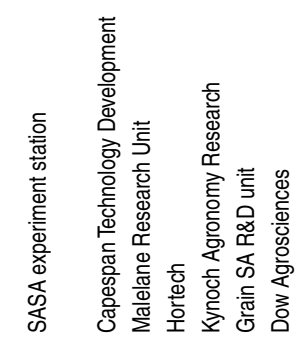

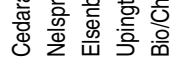

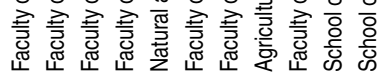

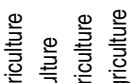

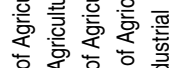

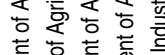

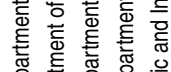

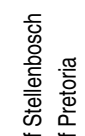

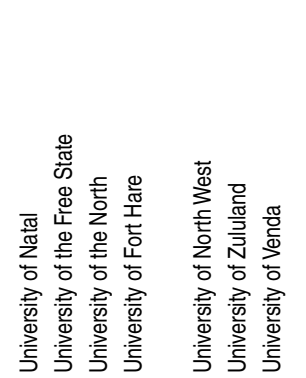

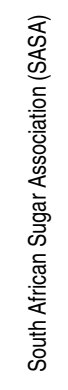

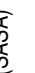

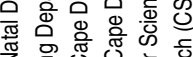

흥

曾

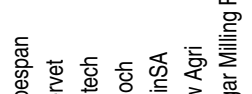

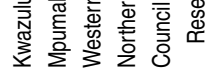

量

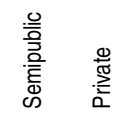

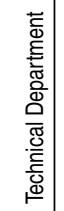




\section{Notes}

1. On May 23, 2002, the first steering committee of NARF was elected by the stakeholders. The committee has developed a number of project proposals on NARS policy issues.

2. Given a poverty line of R352 monthly household expenditure per adult equivalent (May 2000).

3. People not formally employed, which typically includes those engaged in subsistence activities enterprises, casual labor, street traders, and hawking.

4. The DBSA (2000, p. 193) used the following definition for unemployment: persons 15 years of age and older who, during the reference week, were not in paid work or self-employment, were available for paid work or self-employment, took specific steps during the four weeks preceding the interview to find paid work or self-employment, or had the desire to work and would be available to take up a suitable job were one offered.

5. In June 2002 the South African rand was trading at R10.05 to the U.S. dollar, and the World Bank purchasing parity exchange rate was R2.2 to the U.S. dollar.

6. This section draws largely from a paper by van Zyl, Vink, and Kirsten (2001) prepared for the Journal for International Development. See Vink 2000 for a review of recent South African literature on the process and results of deregulation in agriculture since the early $1980 \mathrm{~s}$.

7. Until the 1990s, the policy of the Department of Agriculture was to negotiate with only one representative body of farmers - the South African Agricultural Union (SAAU), now known as Agriculture South Africa (Agri-SA).

8. A group of countries, including Australia, New Zealand, South Africa, Brazil, and Argentina, that support the principle of free trade in agricultural commodities.

9. This refers to the amount authorized annually by the national government for all the science and technology initiatives it funds.

10. For more details, see Roseboom et al. 1995.

11. Following the 1983 referendum, a three-chamber parliament was established, but all government affairs were still classified according to race, with "own" affairs and "general" affairs departments.

12. Levies can be voluntary or statutory, the latter having been introduced under the Agricultural Marketing Act. The rate varies from commodity to commodity, but the National Agricultural Marketing Council prescribes that it should not exceed 5 percent of the guideline price.

\section{References}

Arnade, C., Y. Khatri, D. Schimmelpfennig, C. Thirtle, and J. van Zyl. 1996. Short and long run returns to agricultural $R \& D$ in South Africa, or Will the real rate of return please stand up? In Global agricultural science policy for the twenty-first century: Conference proceedings vol. 2 (contributed papers). Melbourne, Australia.

DACST (Department of Arts, Culture, Science, and Technology). 2001. The science vote. http:// www.dacst.gov.za. Accessed November 26, 2001.

DBSA (Development Bank of Southern Africa). 2000. Development report: Building developmental local government. Halfway House: Development Bank of Southern Africa. 
DNE (Department of National Education). 1988. A System of Framework Autonomy for Science Councils. Pretoria: DNE.

DST (Department of Science and Technology). 2002. South Africa's National Research and Development Strategy. Pretoria: DST.

Groenewald, J. A. 2000. The Agricultural Marketing Act: A postmortem. South African Journal of Economics 68 (3): 364-402.

Khatri, W. E., D. Schimmelpfennig, C. Thirtle, and J. van Zyl. 1996. Refining returns to research and development in South African commercial agriculture. Agrekon 35 (4): 283-290.

Liebenberg, F., N. M. Beintema, and J. F. Kirsten. 2004. South Africa: Agricultural science and technology indicators country brief no. 14. Washington, D.C., and The Hague: International Food Policy Research Institute, International Service for National Agricultural Research, and Agricultural Research Council.

Marasas, C. N., P. Anandajayasekeram, J. G. Niederwieser, M. Coetzee, D. Martella, B. J. Pieterse, and C. J. van Rooyen. 1998. The future of wildflower research and development in South Africa: The Lachenalia case study. Agrekon 37(4): 23-60.

May, J. 2000. Poverty and inequality in South Africa: Meeting the challenge. Cape Town: David Phillip.

Mokoena, M. R., R. F. Townsend, and J. F. Kirsten. 1999. Cattle improvement schemes in South Africa: Measuring the returns to research investment. Agrekon 38 (1): 78-89.

NDA (National Department of Agriculture). 2001. The strategic plan for South African agriculture. Pretoria: NDA.

- 2003. Abstract of agricultural statistics, 2003. Pretoria: Directorate of Agricultural Statistics.

- 2005. Abstract of agricultural statistics, 2005. Pretoria: Directorate of Agricultural Statistics.

Roseboom, J., P. G. Pardey, H. J Sartorius von Bach, and J. van Zyl. 1995. Statistical brief on the National Agricultural Research System of South Africa. ISNAR Indicator Series Project. Statistical Brief No. 23. The Hague: International Service for National Agricultural Research.

SARB (South African Reserve Bank). N.d. Historical data. www.resbank.co.za. Accessed December 2002.

Sartorius von Bach, H. J., and J van Zyl. 1991. Have recent structural changes caused agriculture to become less rigid? Development Southern Africa 8 (3): 399-404.

SSA (Statistics South Africa). 1985. Agricultural census, 1985. Pretoria: SSA.

Thirtle, C. 2001. TFP index for South African agriculture. Unpublished data and monograph. Department of Agricultural Economics, University of Pretoria.

Thirtle, C., and J van Zyl. 1994. Explaining total factor productivity growth and returns to research and extension in South African commercial agriculture, 1947-91. South African Journal of Agricultural Extension 23: 21-27. 
Thirtle, C., R. F. Townsend, J. Amadi, A. Lusigi, and J. van Zyl. 1998. The rate of return on expenditures of the South African Agricultural Research Council (ARC). Agrekon 37 (4): 621-631.

Townsend, R. F., and J. van Zyl. 1998. Estimation of the rate of return to wine grape research and technology development expenditures in South Africa. Agrekon 37 (2): 189-210.

Van Zyl, J., and J. A. Groenewald. 1988. Flexibility in inputs substitution: A case study of South African agriculture. Development Southern Africa 5 (1): 2-13.

Van Zyl, J., N. Vink, and J.F. Kirsten. 2001. South African Agriculture Transition: The 1990s. Journal of International Development 13 (September): 725-739.

Vink, N. 2000. Agricultural policy research in South Africa: Challenges for the future. Agrekon 39 (4): 432-470.

Wessels, J., P. Anandajayasekeram, C. J. van Rooyen, C. N. Marasas, G. Littlejohn, and C. Coetzee. 1998. Does research and development pay? The case for Proteaceae. Agrekon 37 (4): 610-620.

World Bank. 2003. World development indicators 2003. Washington, D.C. CD-ROM. 